\title{
Peder Sjögren - En bortglömd smålänning på frammarsch?
}

\author{
Av Magnus Nilsson, doktorand i litteraturvetenskap
}

\author{
Länk till presentation av Magnus Nilsson
}

Peder Sjögren, född i Braås 1905, är kanske en av de idag mer okända litterära storheterna från länet. Och en av anledningarna till att han inte har rotat sig särskilt djupt i det småländska medvetandet är måhända det faktum att det småländska, med något enstaka undantag, aldrig har varit särskilt framträdande i hans texter, och kanske har även hans tämligen radikalt experimenterande stil under femtio-, och sextiotalen gjort att hans läsare numera är ganska få till antalet. Men lyckligtvis finns det i dag tydliga tecken på att Sjögrens stjärna nu är på uppgång. Till exempel gavs Kärlekens bröd ut i serien "En bok för alla" 1995 och under nittiotalet har även de två första litteraturvetenskapliga avhandlingarna om Sjögrens författarskap publicerats. Dessutom kom så sent som i år Agneta Uppmans bok Tala enkelt om sorgen: En bok om min styvfar Peder Sjögren ut på Norstedts förlag. Och kanske är denna sjögrenrenässans under nittiotalet ett tecken på att Peder Sjögren nu äntligen är på väg att få den uppmärksamhet och den framskjutna plats i den svenska litteraturhistorien och det småländska medvetandet som han så väl förtjänar?

Ofta har han beskrivits som en särling i den svenska litteraturhistorien, som trots att han var flera år äldre än de så kallade fyrtiotalisterna (med författare som Lars Ahlin, Stig Dagerman och Karl Vennberg som de mest framträdande namnen) ofta i brist på bättre brukar placeras in i fyrtiotalistfacket. Och förvisso kan han sägas höra ihop med fyrtiotalisterna på så sätt att skam, ångest och skuld alltid är oerhört centrala teman i hans romaner. Men han är också mycket olik dem i sin syn på kärleken som en obändig naturkraft vilken genomsyrar hela universum, och som trots att den drabbar människor som en förödande orkanvind är det enda som gör det möjligt att leva ett autentiskt liv. Och samtidigt är kärleken också så stark att naturen obönhörligt och grymt straffar de som förnekar den.

Detta idékomplex är mycket centralt i Sjögrens kanske mest kända roman Kärlekens bröd (1945) som utspelar sig under finska vinterkrigets helvete, som Sjögren kände väl till genom egna erfarenheter. Det är ingen ordinär kärleksroman, utan det är en roman där Sjögren kombinerar fyrtiotalets pessimism och avsaknad av en tro på människorna med en nästan paradoxal tro på Kärleken. Och det är även en roman om möten mellan människor som alla står i speciella förhållanden till naturkraften Kärlek. För även om det är en mycket intensiv skildring av krigets fasor och dess effekt på människor, är ändå det centrala temat i romanen kärlekens nödvändighet och dess kraft att överleva och segra, även under de svåraste förhållanden. Och som en säregen stämningsskapande lykta som belyser scenen där allt detta utspelar sig finns hela tiden månen; ömsom spridande sitt kalla ljus över liken som ligger utspridda i skogarna och ömsom som en förmedlare av den starka kärleken mellan romanens egentliga huvudpersoner - den ryske krigsfången Plennik och hans kvinna Lúnnaja, som tack vare sitt oerhörda bejakande av kärlekens kraft lever med och i varandra, trots att kriget har skilt dem åt och de nu befinner sig på var sin sida om frontlinjen.

Den första gång Plennik dyker upp är i bokens kanske vackraste scen, när han talar till månen för att med dess hjälp kunna nå Lúnnaja. Rakt upp mot det kalla månljuset berättar han om sina bravader på flykt från sitt kompani på väg till den by där han tror att hon finns, och trots det ytligt sett absurda i denna scen är det hela skildrat med en sådan 
intensitet och i ett sådant magiskt skimmer att det ändå blir en mycket stark och vacker bild av hur äkta kärlek kan överleva och segra även i den mest livsfientliga miljö man kan tänka sig.

En annan sida av kärleken, som är ofta återkommande hos Sjögren och som även är mycket tydlig i Kärlekens bröd, är att den allra mest förödande och förgörande kraft som finns är kärlekens frånvaro. De som står i ett avvisande eller bristfälligt förhållande till Kärleken framstår alla som mänskligt sett förfelade människor med förkrympta andar som naturen obönhörligen straffar genom att låta dem leva i kärlekslöshetens kalla och tomma öken (i Kärlekens bröd väl illustrerad med det krigshärjade Finland som sinnebilden för hur världen blir utan kärlek), medan de som tror på kärleken framstår som de enda levande människorna, som likt Plennik och Lúnnaja lever och överlever med månen som beskyddare i ett bitande kallt krigslandskap.

(Artikeln även publicerad i Smålandsposten 971014 med rubriken 'En stjärna på uppgång') 